\title{
The Dominant Peoples in History according to Grundtvig and Hegel
}

\author{
By Tord Ehnevid
}

A comparison between Grundtvig and Hegel can be justified on several grounds. Grundtvig was younger than Hegel by thirteen years and gained recognition and authority in his homeland much later than Hegel in Germany. Any historico-genetic connection between Grundtvig and Hegel can, therefore, be imagined in one direction only: from Hegel to Grundtvig, not from Grundtvig to Hegel. In searching through the Grundtvig material, however, one finds that Grundtvig's views on Hegel's philosophy are only briefly and rarely expressed. What he does say, moreover, is invariably unfavorable. The areas of contact between Grundtvig and Hegel appear to be so small that a comparison between them would seem to have little to yield from the historico-genetic point of view.

Looking at Grundtvig and Hegel today in the perspective of time, however, one immediately finds the grounds for comparison more productive. Both men have undergone a renaissance as sources of inspiration to those who are critical of the static one-sidedness of analytical philosophy. The trend today is for the concept of "history" to be replaced by that of "science". Science includes analysis in vacuo according to certain rules of thought - formal logic - and experience based on so-called facts resulting from systematically varied experiments. Both Hegel and Grundtvig consciously worked out their system of thought, rejecting the cultural tradition on which the static and mathematical character of the modern scientific ideal has been based. Thus Hegel seeks to replace so-called positive logic by negative logic. Grundtvig writes of chrono-logic. One is reminded in this connection of Grundtvig's criticism of working methods according to which everything has 
to be measured. The "gauge" in Grundtvig's usage is not only a reference to such systems but also a term for evil.

Logical empiricism has become the designation of a trend in philosophy which would reject both Hegel and Grundtvig as scientists. If the term "logical empiricism" had not had this ideo-historical connotation it would have aptly summed up Hegel's and Grundtvig's programme of ideas. Logic occupies an important place in the thinking of both of them. They regard logic, however, as something not static but dynamic. Logic is determined by motion, not rest; by time, not space. Nor is experience determined by space. Experience is temporal, historical. If it were not so it would shrink into so narrow a perspective as to become unscientific. History, therefore, is an appropriate term for an academic or scientific field, as in, for instance, the history of religion, of literature, of society, and so on.

With history occupying such a prominent place in Hegel's and Grundtvig's worlds of thought, it should be possible to discover the characteristic features of them both by studying the way in which each of them presents history. Both use the expression "the dominant peoples in history". The study could, therefore, be narrowed down to these peoples. In making their selection Grundtvig and Hegel applied the principles which they considered crucial to the progress of mankind. One obvious requirement with both of them was a clear movement forward in mankind's history, not a cycle. A cycle is natural to space, not to temporal history.

Grundtvig's dominant peoples are seven in number. Six are famous in history. The seventh can only be prophesied about. The six dominant peoples are in turn the Hebrews, the Greeks, the Romans, the Anglo-Saxons, the Teutons and the Scandinavians. Hegel reckons with four dominant peoples: the Persians, the Greeks, the Romans and the Germans. As to the future, he makes no prophecy.

As will be seen, the peoples Grundtvig and Hegel have chosen are much the same. To Hegel's Germans, who are mainly Teutons, may be added Grundtvig's Anglo-Saxons and Scandinavians. This narrows the difference down to the first of the dominant peoples: in Hegel's view the Persians, in Grundtvig's the Hebrews. Hegel does in fact include the Hebrews among the Persians, since the kingdom of Persia also comprises the land of Canaan. The difference nevertheless remains. The Persians' contribution to history is 
not of sufficient value in Grundtvig's view to warrant them a place among the dominant peoples in history.

There is another respect in which Grundtvig's and Hegel's chains of dominant peoples differ. With Hegel the path of history is straighter. Each new dominant people brings a step forward. This is not the case with Grundtvig. From the Hebrews to the Romans is a step backward. With the Anglo-Saxons the march forward resumes and continues without interruption.

Neither to Grundtvig nor Hegel is the choice of dominant peoples arbitrary. The writing of history is not a self-chosen, critical and reflective process. Form and content are not separate. The writing of history is at one with the course of history. The writer of history moves, as it were, alongside the historical material. $\mathrm{He}$ is able to do so since he himself is part of time. The same forces are at work in him as in mankind. As a spiritual being he can move through history on the wings of the spirit. By doing so he can also determine which are the dominant peoples in history.

Self-consciousness (Selbstbewusstsein) is not static but historical. It increases and develops as time progresses. History is a conscious process, like the individual's life. The conscious process might equally well be described as a thought process. Thought obeys definite laws which are described in logic. To be oneself is to affirm oneself. The first proposition in logic is the proposition of identity. To affirm oneself is to deny what is not oneself. And so the second proposition in logic is formulated, the law of opposition.

To summarize: to be oneself is a conscious process, a thought process, a process, moreover, dependent on truth. The same logic is inherent in history, enabling the writer of history to understand history.

A person cannot be himself unless he is free to be himself. Identity implies the freedom to affirm oneself. Self-affirmation must come from within. Self-consciousness cannot be achieved by force. History, however, is well-known to contain many examples of force and other acts of compulsion against the individual. Such encroachments on freedom inhibit progress.

Freedom, therefore, characterizes the progress of history. Hegel likens freedom to the law of gravitation in nature. Objects seek a central point in free fall. In the world of the spirit freedom plays 
a similar role. But, unlike the material world, the spirit has its central point within itself. Self-consciousness is to realize that the nature of man is to be free and to work for the attainment of this freedom. Such thoughts lead Hegel to conclude: "World history is progress in the consciousness of freedom".

To Grundtvig, too, freedom is a key word, even if he knows that it is capable of many meanings. "As slippery as an eel" he calls it. Freedom is the atmosphere in which truth, and therefore history, thrive, for history is an increment of truth. "Where the spirit of the Lord is, there is freedom" is a saying of Grundtvig's which is frequently quoted. Still clearer is the call for freedom in the following lines:

Only to Hell can man be forced; to Heaven he's simply called;

Freedom follows the spirit of truth.

So far I have linked the principle of freedom as enunciated by both Hegel and Grundtvig to the individual in a way which might be misunderstood. The individual's craving for freedom in order to realize his consciousness of self might be opposed to the interests of the general public and of mankind in general. Such an idea is foreign to both Hegel and Grundtvig. The individual can be himself only in community with others. To Grundtvig this community is the people. Hegel calls it the State.

A people, according to Grundtvig, are those having a common language. The hallmark of the individual is his language. In it reposes his likeness to God. God is the invisible Word. Man has been permitted to retain the Word despite the Fall. By safeguarding his word he safeguards his bumanity. A person's word is always a word taken from a people's language. In the mother tongue the spiritual lives of the individual and of the whole people find expression. Those people who have managed to retain and develop their community of language most successfully are counted the dominant peoples in history. Of the dominant peoples one has managed to achieve an importance of a negative kind in history. The Romans long impeded progress by forcing Latin on other peoples.

In Hegel's view community of language is of minor significance. The crucial factor in a people is whether they form a State. "In world history the only peoples that matter are those that form a State", for the State is "freedom come to realization". Hegel reaches 
this conclusion because he attaches importance to man as a rational being. Reason rules the world and guides the progress of world history. The rational activities of individuals find expression in the laws and customs of the State, providing an instrument from which the world significance of a people can be determined.

In this connection it is interesting to compare Hegel's and Grundtvig's assessments of poetry and prose. Hegel praises the prosaic common sense of the Hebrews. Grundtvig, on the other hand, considers them poetic. The difference between Hegel and Grundtvig is most clearly expressed in their views on folk mythology. In Grundtvig's view a people's history begins with their myths, which reflect the conditions prevailing amongst the people during what was probably their best period, their golden age. Being poetic, the language has continuity. When a people becomes prosaic it ceases to be significant in world history.

In Hegel's view myths are external to history. "History is prosaic, and myths so far contain nothing of history." Only by the use of abstract definitions can a people express itself in its laws. Prose is thus a prerequisite of the formation of a State. It might be said, in fact, that the more poetic a people the greater, in Grundtvig's view, its role in world history. The more prosaic a people the greater, in Hegel's view, its chances of making a contribution of world significance to politics. With Grundtvig "the living word" in history is the determining factor in assessing poetry and prose; with Hegel it is "reason".

The time has now come to take a closer look at the various dominant peoples. Let us start with Grundtvig's list. Grundtvig fixed the number of dominant peoples according to the seven Churches of the Book of Revelations, although general history is not normally determined by Christian attitudes. General history is part not of God's work of salvation but of His work of creation. Grundtvig's starting point is Deuteronomy 32, v. $8 \mathrm{f}$. God has set the bounds of the people according to the number of his angels. Each people has its own angel, "its good Spirit". This Spirit works in the language of the people. The closer a people's language approximates to the original Divine language, the greater the significance of that people in history.

The Hebrew people stands in a special position since their language is kyriological, i. e. the Lord's own language. It is the 
language which is least corrupted. But, seen from Grundtvig's time, it has the misfortune of being a dead language. The significance of Israel in world history is intensified by the fact that the Old Testament history of Israel also illuminates the history of other peoples. Grundtvig mentions the Egyptians, the Assyrians, the Babylonians, the Medes and the Persians.

After the Hebrews come the Greeks. From the wealth of their literature the significance "the living Word" once had for them is clear. Just as the Old Testament was written in Hebrew, so it followed that the New Testament was written in Greek. The struggles of the Greeks for freedom in antiquity acquired fresh topicality in Grundtvig's time, when the Greeks succeeded in liberating themselves from the domination of the Turks.

When the Romans deprived the Greeks of their freedom the Greeks ceased to write in poetry. Latin grammar crushed the living language of the conquered people. For centuries Latin was the language of church and school. The Romans' conception of man was, in Grundtvig's view consistent with their lust for conquest. According to legend, the founder of Rome was descended from a she-wolf.

The period of spiritual greatness of the Angles is associated with such names as the venerable Bede and Alcuin. From the Angles missionaries went out to Germany (St. Boniface) and the North. Grundtvig had himself worked on the epic poem, "Beowulf", a further indication of the force of "the living word" once in England.

With Luther the Germans became one of the dominant peoples in history. The Germans received the Bible in their own language. Latin gave way in church services to the language of the people. Hymns began to be sung in the vernacular.

The sixth of the dominant peoples are the Scandinavians, in particular the Danes. Nordic mythology is unique. No other people has pondered so deeply over the mystery of life and has sought so intensively the answer in the mists of time as the Scandinavians have done. Yggdrasill, the vast ash-tree which is the entire universe, has no counterpart in detail and poetic power in the mythology of any other people. Thanks to Grundtvig these powerful myths have gained renewed life on the lips of the people.

In the seventh of the dominant people, which is still to come, the spirit of community will flourish. They will sing in the full 
fervour of their native tongue. Grundtvig prophesies that the people of the future will be the Indians.

Hegel's divining-rod for finding the dominant peoples in history is reason rather than "the living word". As the sun illuminates the earth from east to west so Hegel sees history developing from east to west. In the "oriental world" there is no history at first since no change is possible. Change presupposes consciouness of "the contrast between an objective existence and the subjective movement alongside it". In China the substantial spirit and the individual spirit are regarded as a natural unit. The individual spirit does not recognize its own freedom. Freedom is not a subject for thought. It will not produce a state constitution. Nor in the field of religion is it reasonable to differentiate between the objective spirit and nature. The concept of "tien" comprises both heaven and nature.

India, too is static. Unlike China, India is ruled by idealism. But it is "an idealism without ideas born of the imagination". India's spirit is dreaming, the result being that the individual does not feel himself to be detached from things. In China the State was all; in India the People are all. In neither case does the individual recognize himself as being self-conscious. Nor do the people come to consciousness, this being possible only through the history of the people's laws and customs.

In the oriental world a historic people first appears with the arrival of the Persians. Zoroaster's concept of light implies consciousness of a spirit standing in relation to something else, namely darkness. The contrast between light and darkness implies action and life. History can begin. According to Hegel the conquest of the Semitic Middle East by the Persians will have historic consequences for the world. The Middle East is the home of traders with an industrial economy who ship their products across the sea. For the first time man's industry and reason are more important than nature and her products. Thanks to industry man loses his fear of nature and finds an aim in life within himself. Through their connection with the Persians the Jews also contribute to world history. The light of the Persians, which still describes spiritual things in sensual terms, can give way to the abstract principle of Jahve (Jehova), the one and only. Nature is reduced to a creation of Jahve. Only the spirit is truth. Thought is free to formulate true morality and justice according to God's will. But the absolute has 
still to be conceived as a concrete spirit, and so the subject is not concretely free either. The Egyptians' contribution to the liberation of the spirit is the concept of the immortality of the spirit.

With the Greeks the individual liberates himself entirely from all ties with nature. The law, rather than the family, is now the basis of the community. The Greeks make use of nature but transform it into spirituality. Stone becomes a spiritual work of art. The "forms of beautiful individuality" are classified by Hegel into three divisions. The first he calls subjective works of art, comprising tools, games, jewellery and singing. Objective works of art comprise the Greek' conception of the Gods as material beings, as real people. Finally there is the political work of art, the State, which combines within it both the subjective and the objective works of art. The State's constitution is a democracy, in which individuals can develop their freedom to create laws, which are regarded as beneficial. Socrates, in Hegel's view, was the inventor of morality, having demanded that people shall be conscious of their actions.

The Romans created abstract freedom in the abstract State. This abstract State has its counterpart on the individual level in the personality, which, says Hegel, is not the same thing as individuality. Personality is the basic attribute of justice and has its clearest manifestation in private property. The abstract State, with its personalities, i. e. individual abstract freedom, pays no regard to the living spirit and its individuals. It pursues its aim - domination - ruthlessly. As an example of the cold abstraction of domination Hegel cites Cato's advice to the Senate: Ceterum censeo Carthaginem esse delendam.

The abstract State and civil law together led the Roman Empire to the brink of dissolution. The absolute ruler was a "monas monadum" in relation to the private individuals, their subjects. Christianity, by contrast, achieved reconciliation between the higher spirit and the individual. Man, who is himself a spirit, is present in his absolute object, in the truth, in God. In the Germanic world this reconciliation is transferred to society in its entirety.

Church and State represent two different principles standing in opposition to each other. During the first period of the Germanic world down to Charles the Great the spiritual and the worldly are two aspects of the same thing. The second period brings tension 
between theocracy and the feudal monarchy. The triumph of the monkish ideal means the negation of morality. The monk's vows of poverty, chastity and obedience were by implication a disparagement of work, marriage and freedom. The Reformation introduces the third period, in which the State and Church, justice and religion, are reconciled. Marriage becomes moral. With Luther's view of work, industry and craftsmanship also become moral. Everyone has a conscience and is free to obey it. Protestantism gradually obtains a State, Prussia, which will defend it. The next stage in history is the Age of Enlightenment. What Luther described as a phenomenon revealed in history by religion now becomes part of the age. As Luther expresses it, the conquest of spiritual freedom and the concrete reconciliation takes place in man himself. During the Age of Enlightenment this philosophical principle is established abstractly in all its universality. The principle consists of the combination of opposition and identity into one fundamental principle. During the final stage of history this principle will be realized in the realm of the wills. The will is free when it wills itself, i. e. when the individual wills will the general will. "The will willing itself is the basis of all justice and of all commitments and therefore of all laws."

Hegel thus bases his conception of history on a philosophical principle. The two principal laws of logic, the law of identity and the law of opposition, determine the course of events. Grundtvig, too, sees history as a revealer of "the principle of truth", which is the single name he uses for the law of identity and the law of opposition. It is at this very point, however, that Grundtvig attacks Hegel's concept. In "Budstikke i Højnorden" Grundtvig writes that the German's God is reason, raising itself above affirmation and denial "on Hegelian jacks". "Affirmation and denial against each other cannot make one", as Grundtvig had already declared in Dannevirke. But this is what happens with Hegel. Hegel uses the order "opposition and identity" in his philosophy of history. Immediacy, i. e. unconscious identity, makes a people unhistoric (e. g. China). Only by conscious negation are movement, change and history imparted. Hegel's analysis of the Fall follows the same line. "Paradise is a park where only animals, not men, may be". The natural person, like animals, is neither good nor bad. The conscious person, on the other hand, differentiates between the 
ego with "its infinite freedom as its conditions" and "the pure content of the will, good". Hegel refers to the Fall as "the eternal history of the spirit". Only when man has experienced himself as himself, i. e. as a spirit, in the Fall, does he become a real person. But at he same time he separates himself in his abstract freedom from the universal divine spirit. And in doing so he finds himself in evil. Knowledge of the difference between good and evil thus constitutes evil but is also the driving force whereby man seeks reconciliation. On the path to knowledge man finally achieves this reconciliation, first through the revelation in Christ and then as a willing will.

To Grundtvig such an interpretation of the Fall is absurd. The essence of the Fall is man's greater belief in the power which makes God a liar than in the God of truth. Man cannot possibly come nearer the truth by making common cause with the lying devil. On the contrary, man rejects the devil before speaking the language of truth in the creed of God's people. This attitude to God and against the devil also applies to those who do not belong to God's people. To speak one's own language and to preserve it is to affirm the language one has received from God, even if subsequently it should have become corrupted. In seeking to imitate the language of others one is affirming a power hostile to God.

Despite his consciousness of the distance separating him from the Hegelians' view of the Fall, Grundtvig is ready in the name of spiritual freedom to carry the discussion further. For Grundtvig sees the positive aspect of Hegel's recognition of the historical data as "the essential starting point". With his conception that man can redeem his Fall in a natural way, Hegel in Grundtvig's view joins the naturalists. In schools Grundtvig can visualize competition between his own attitude and Hegel's. History, of course, provides a basis for both attitudes.

The goal of history in Hegel's view was a form of State in which State and Church supported each other. Both cherished the principle of reconciliation and mediation. The general will would be reconciled with the individual wills. Any such line of thought was foreign to Grundtvig. The people of God, God's free assembly, could of course influence a worldly people so that their language and mode of thought became more fervent and heartfelt. By virtue of its constitution a free National Church could smooth relations 
between ecclesiastical and state bodies in the most effective manner possible. But towards the end of history it would nevertheless become apparent that State and Church were irreconcilably opposed to each other. In the final conflict of history between God and the devil, truth and lies, only those who were part of God's people could survive.

Grundtvig believes that, with his dialectics, Hegel has himself proved that truth in the form of identity is the eternal truth. "Truth cannot be denied without thereby being confirmed". Høirup deserves the credit for having extracted from Krønnike-Rim in his doctoral thesis this pronouncement of Grundtvig's. It is interesting to see how Grundtvig puts Hegel on a par here with "the Holy Roman Empire" which will both "be and not be". In Hegel's account of history the Holy Roman Empire constituted the first phase in the historical development of the Germanic world. But it is only with Luther as the defender of the individual's conscience and with Prussia as State protector of Protestantism that, according to Hegel, reconciliation is achieved between State and Church.

In his brief explanation of the implications of Hegel's dialectics, Grundtvig has shown what unites and what divides them. To both Grundtvig and Hegel logic and history are indissolubly linked. The principle of truth is the basis of the conceptions of them both. According to classical logic the principle of truth consists of three laws: identity, opposition, and the law of the excluded middle. Grundtvig keeps them in this order. With Hegel opposition, negation, forms the starting point. Only then does identity follow. And there is no room for the law of the excluded middle.

Logic leads Grundtvig to history's goal, where truth, as identity, remains the sole victor. Hegel's logic leads to the attainment of history's goal; negation remains latent (as exclusion?), while the opposites are reconciled in a higher identity. Logic, too, then becomes the instrument involved in the selection of the dominant peoples in history. Both "the word" in Grundtvig's writing of history and reason in Hegel's follow the laws of logic. Chrono-logic and dialectics take care of the time dimension in mankind's existence. 
References (abbreviations used in the notes within parentheses)

1. Grundtvig's works (Place of publication is Copenhagen)

Nik. Fred. Sev. Grundtvigs udvalgte Skrifter ved Holger Begtrup I-X. 1904-1909 (quoted as I, II a. s. o.)

N. F. S. Grundtvigs Poetiske Skrifter I-VII udgivne af Svend Grundtvig 1880 1889, VIII-IX efter Forarbejder af Svend Grundtvig udgivne af Georg Christensen, 1929-30 (quoted as PS I a. s. o.)

Udsigt over Verdens-Krøniken fornemmelig i det Lutherske Tidsrum. 1817.

Sangværk til den danske Kirke (Psalmer og aandelige Sange I). (1837)

2. uppl. 1868.

Krønnike-Rim til levende Skolebrug, med Indledninger og Oplysninger. (1828). 3 uppl. 1875.

Sidste Prædikener. I Vartov Kirke 1861-72. I-II (Et Udvalg af C. J. Brandt). 1880.

\section{Hegel's works}

Wissenschaft der Logik I-II (Hegel, Sämtliche Werke, ausgegebene von Hermann Glockner, Band 4-5). 3 uppl. Stuttgart 1958.

Vorlesungen über die Philosophie der Geschichte (Georg Wilhelm Friedrich Hegel, Werke in 20 Bänden, Band 12). Frankfurt am Main 1970.

\section{Other works}

Ehnevid, Tord. Församlingsetik. Studier över Grundtvig. Morten Pontoppidan och Einar Billing. Lund 1969.

Høirup, Henning. Grundtvigs Syn paa Tro og Erkendelse. Modsigelsens Grundsætning som teologisk Aksiom hos Grundtvig. København 1949.

\section{Notes}

To page 115, line 28:

Hegel's criticism of analytic logic is apparent, for example, from Hegel 1958 I, p.49. Concerning logic in history see Hegel 1970 p.86.

To page 115, line 29:

IV p.705; Ehnevid 1969 p.21.

To page 116, line 2:

PS IX pp.298. The "gauge builds the tower of Babel. Pride leads to the confusion of tongues.

To page 116, line 30:

Hegel 1970 p.22.

To page 117, line 8:

Grundtvig 1880 I pp.420.

To page 117, line 27 :

The Spirit of truth will guide you into all truth. John 16.13.
To page 117, line 37 :

Hegel 1970 p.30.

To page 118, line 4:

Op.cit. pp.20.

To page 118, line 7:

Grundtvig 1875 p.245.

To page 118, line 11:

Grundtvig 1868 p.109.

To page 118, line 34:

See further Ehnevid 1969 p.57.

To page 118, line 38:

Hegel 1970 p.56.

To page 119, line 2:

Op.cit. pp.20.

To page 119, line 14:

Ehnevid 1969 p.54.

To page 119, line 16:

Hegel 1970 p.142. 
To page 119, line 28:

Ehnevid 1969 p.55.

To page 119, line 31:

Op.cit. p.51 note 26.

To page 120, line 6 :

Op.cit. p.56.

To page 120, line 25:

Grundtvig 1817 pp.79.

To page 121, line 10:

Hegel 1970 p.147. About the relation between objective and subjective in Hegel's logic see e.g. Hegel 1958 I p.60.

To page 121, line 11:

Hegel 1970 p.152.

To page 121, line 17:

Op.cit. p.175.

To page 121, line 20:

Op.cit. p.201.

To page 121, line 21:

Op.cit. p.202.

To page 121, line 38 :

Op.cit. p.241.

To page 121, line 39:

Op.cit. p.242.

To page 122, line 13:

Op.cit. p.301.

To page 122, line 19:

Op.cit. p.32.

To page 122, line 20:

Op.cit. p.340.

To page 122, line 24:

Op.cit. pp.342 and 383.
To page 122, line 29:

Op.cit. p.374.

To page 122, line 32:

Op.cit. p.387.

To page 123, line 1:

Op.cit. p.415.

To page 123, line 11:

Op.cit. p.523.

To page 123, line 22:

Op.cit. p.540.

To page 123, line 31 :

PS IX p.108.

To page 123, line 33:

Ehnevid 1969 pp.21 and 95.

To page 123, line 35:

Hegel 1970 p.524.

To page 123, line 38:

Op.cit. p.389.

To page 124, line 9:

Op.cit. p.391.

To page 124, line 28:

VIII pp.168. The statement is made in 1837.

To page 125, line 7:

See Ehnevid 1969 p.86.

To page 125, line 14:

Grundtvig 1875 p.250; Høirup 1949 pp.87.

To page 125, line 28:

Hegel 1958 I pp.544.

To page 125, line 31:

Høirup 1949 p.118 note 3; Hegel 1958

II p.242. 